\title{
THE FIFTIETH ANNIVERSARY OF THE PASSAIC TEXTILE STRIKE
}

On October 16, 1976, the William Paterson College of New Jersey hosted a public symposium to commemorate the fiftieth anniversary of the Passaic textile strike of 1926. Co-sponsors of the day-long program included the New Jersey Historical Commission, the New Jersey Urban History Association, and the labor education division of Essex Community College. Although publicity announcing the program was ignored by major metropolitan press and media outlets, the symposium attracted an audience of almost 100 persons composed of academicians, labor union members, and various "movement activists" whose experiences spanned the period from post-World War. I to the present.

The Passaic textile strike of 1926 is of major importance to both historians and students of contemporary society. It dominated the metropolitan and national press intermittently for nearly a year and had far-reaching significance in many areas of American life during the interwar years. In the words of historian Paul L. Murphy, "the ambitions and frustrations of both management and labor were strongly affected; the immigrant question was brought into sharp focus; the role of the police and local courts came to the fore and raised critical questions about both of them." Arthur Garfield Hays of the American Civil Liberties Union observed at the time of the strike that "one cannot conceive of a greater state of organized tyranny and disregard of the law." In fact, at one time or another an impressive array of nationally-known figures lent their names. and in some cases their energy, to the strikers' cause.

A ten percent wage reduction in Passaic's major textile mills caused the strike. The labor force was largely foreign-born and poorly educated, and it included a goodly number of women and children. Violence erupted. In the absence of initial support from the American Federation of Labor, a Communist-dominated United Front Committee provided leadership. Playing a principal role was Albert Weisbord, a Phi Bera Kappa graduate of The City College of New York and recipient of a law degree from Harvard. When the A.F. of L. agreed to organize the workers provided that Weisbord withdraw from the strike leadership because of his party affiliation, the employers still refused to recognize the union. But as professor Murphy has pointed out in his documentary history of the strike, the new tech. niques deployed to attract public support for the workers "forecast the strategies of the strikes of the 1930s." Management's use of the "Communist issue" also presaged the next decade. Eventually manufacturers yielded to certain limited worker demands and the strike was settled in February, 1927. Essentially, however. Passaic remained a nonunion mill town.

The goals of the symposium, as ordained by the New Jersey Committee on the Humanities which underwrote the entire program, were: 1) to examine this important event in the labor history of the state. 2) to record the reminiscences of participants in the strike, and 3) to provide a public educational forum and initiate discussion on the subject. Persons interested in knowing more about devising similar "public history" programs should contact Paul A. Stellhorn. Research Director of The New Jersey Historical Commission, 113 W. State Street. Trenton. New Jersey 08625. Mr. Stellhorn was instrumental in developing this program as a grant proposal.

The morning session of the symposium was academically oriented. Entitled "the Historians' Perspective," it featured two scholarly papers. Michael Ebner, Lake Forest College, spoke on "Strike Activities in Passaic, 1875-1926," placing the major event in the context of the city's overall evolution from village to industrial center. Paul Murphy, University of Minnesota, then delivered a paper on 
"the Passaic Textile Strike of 1926" in which he placed the local events in their national perspective. The symposium chairperson, Rudolph J. Vecoli of the Immigration Research Center at the University of Minnesora offered extended comments on these presentations.

Following luncheon an afternoon session entitled "the Participants Perspective" took place. Leading this segment of the program was Paul Buhle, co-director of the Oral History of the American Left Project at Tamiment Institute of New York University. Most notable among the participants were Albert Weisbord and Vera Buch Weisbord, who had been active in the events fifty years earlier; several other persons who had been on the scene also shared their recollections. In order to preserve this aspect of the program for future historians, the remarks of the participants were taped. Considerable controversy arose, particularly between Albert Weisbord and members of the audience, as to the exact role of the Communist party in Passaic. (Weisbord had been expelled from the C. P. in the strike's aftermath, and subsequently has accused its leadership of sharing responsibility with that of the A. F. of L. for the betrayal of the workers' cause.) This portion of the day generated so much enthusiastic interchange that although the symposium had already gone on for six-and-a-half hours, the discussion was continued for an additional hour.

\section{Michael H. Ebner \\ Lake Forest College}

\section{SELECTED BIBLIOGRAPHY}

Hollander. Jay Michael. "Prelude to a Strike." Proceedings of the New Jersey Historical Society, Vol. 79 Ouly, 1961).pp. 161-168.

Liberman, Esther. "The Influence of Left-Wing Radicalism in the Paterson Silk Strike of 1912-13 and the Passaic Woolen Strike of 1926." Unpublished ms.. 1963, on deposit in the New Jersey Collection of Rutgers University Library. New Brunswick.

Murphy. Paul L.. The Passaic Textile Strike of 1926. Belmont. Ca.: Wadsworth, 1974.

Siegel, Morton. "The Passaic Textile Strike of 1926." Unpublished doctoral dissertation, Columbia University, 1953.

Weisbord. Albert. Passaic Reviewed. (retrospective remarks), $\$ 1.50$.

- The Passaic Textile Strike of 1926. (reprint). \$2.00.

Weisbord, Vera Buch. A Radical's Life. Bloomington: Indiana University Press, 1977, \$15.00.

Available postpaid from the Germinal Press. 114 th Street. San Francisco. CA.

The first annual meeting of the Social Science History Association was held at the University of Pennsylvania on Ocrober 29-31, 1976. The program included a session on "Work and the Family in Industrial Society" organized by the Workers and Industrialization Network of the SSHA. Papers were presented by William Reddy (Harvard University). Susan Kleinberg (Miami University, Oxford), and Laura Strumingher (SUNY Fredonia). For further information contact David Montgomery. Department of History, University of Pittsburgh, Pittsburgh, PA 15260 